\title{
QUANDO APRENDER É PERDER TEMPO.... COMPONDO RELAÇÕES ENTRE LINGUAGEM, APRENDIZAGEM E SENTIDO ${ }^{1}$
}

\author{
Carime Rossi Elias \\ Margarete Axt \\ Universidade Federal do Rio Grande do Sul
}

RESUMO: Quando aprender é perder tempo.... compondo relações entre linguagem, aprendizagem e sentido. O artigo tece considerações acerca de relações entre concepções de aprendizagem e concepções de linguagem na escola. A um concepção de aprendizagem como transmissão de informações/ conhecimentos, articula-se uma concepção naturalizada de linguagem, como código transparente e neutro, pretendendo representar as coisas. Uma concepção de aprendizagem como construção/ desconstrução, por sua vez, teria como correlato uma concepção de linguagem como produção, tomada em sua natureza polissêmica. A argumentação é realizada a partir da obra de Gilles Deleuze que propõe que, para além das dimensões clássicas da linguagem - manifestação, designação e significação - que, em última instância, contribuem para que a linguagem seja tomada somente em sua função comunicativa, há que se levar em conta também a dimensão do sentido/acontecimento.

PALAVRAS-CHAVE: aprendizagem - linguagem - sentido

\section{WHEN LEARNING IS WASTING TIME.... IN THE MIDST OF LANGUAGE AND MEANING}

ABSTRACT: This text interlaces considerations about the relations between learning conceptions and learning conceptions in the school. Into a conception of learning as the transmission of information/ knowledge, it is articulated a conception naturalized in language as a transparent and neuter code that intends to represent things. A conception of learning as construction/deconstruction would have, in its turn, as a correlate, a conception of learning as production of the world taken in its polysemous nature. The argumentation is based on the work of Gilles Deleuze who proposes that beyond the classic dimensions of language - manifestation, designation and signification - which ultimately contribute to language to be taken in its communicative function -, it has also to be considered the dimension of meaning/event. KEY WORDS: learning - language - meaning

$\mathrm{Na}$ contemporaneidade, muitos dos referenciais que fundamentavam o fazer pedagógico estão sendo desconstruídos. A instabilidade, a desordem, a multiplicidade, as diferentes condições de verdade, nos convocam a outros modos de ver, sentir, agir, olhar, pensar. Também o movimento do aprender vem sendo questionado. O que significa aprender quando já não se acredita mais na existência de uma verdade única, quando se questiona o papel da rememoração, da possibilidade de transmissão direta de conhecimentos/informações, do suposto controle do movimento do aprender por parte do professor (e também do aluno)?

Neste contexto, o presente artigo trata de tecer algumas considerações acerca das relações entre concepções de aprendizagem e concepções de linguagem na escola. Parte-se do pressuposto de que a uma concepção de aprendizagem como transmissão/apreensão de informações/conhecimentos liga-se uma concepção naturalizada de linguagem, como código transparente que funciona de modo neutro e tem o papel de representar as coisas do mundo. Por outro lado, uma concepção de aprendizagem como construção/desconstrução, como processualidade, teria como correlato uma concepção de linguagem tomada em sua natureza opaca, polissêmica, a partir de seu movimento de produção do mundo (e não de representação dele).

A argumentação é realizada a partir da obra de Gilles Deleuze que propõe que, para além das dimensões clássicas da linguagem - manifestação, designação e significação - que, em última instância, contribuem para que a linguagem seja tomada somente em sua função comunicativa, há que se levar em conta a dimensão do sentido. 
Elias, C.R.; Axt, $M$ "Quando aprender é perder tempo... compondo relações entre linguagem, aprendizagem e sentido"

DIMENSÕES DA LINGUAGEM E

PRÁTICAS PEDAGÓGICAS

Nesse movimento de crise das instituições, por um lado, a escola parece continuar investindo na tentativa de domar o processo do aprender, medir seus resultados, fazer crer (a professores, alunos e comunidade escolar, ou seja, à própria escola) que seus caminhos são iguais, tanto no que se refere aos percursos percorridos e aos resultados obtidos, como no que concerne aos saberes necessários para atingi-los.

A aprendizagem escolar, concebida como transmissão de informações/conhecimen-tos, é marcada por pontos de partida e pontos de chegada previamente definidos. Movimento supostamente homogêneo, funcionando como elemento disciplinador, a partir de uma idealidade totalizante que deve responder a uma certa ordem e a uma determinada disciplina com vistas a atingir determinados resultados.

Esse modo de entender o aprender escolar articula-se a uma concepção transparente, explícita de linguagem como código, cuja função pode ser definida nos moldes das teorias da comunicação, da seguinte forma: o professor emite uma mensagem que chega ao aluno e é apreendida por ele tal qual foi emitida.

Nesta perspectiva, se o aluno não aprende, se não segue o caminho pré-determinado, é porque não consegue ficar quieto, não consegue compreender, não se adapta à disciplina. Tais práticas de rotulações negativas são confirmadas muitas vezes pelos mais variados diagnósticos psicológicos classificatórios possíveis: hiperatividade, problemas cognitivos, problemas comportamentais e/ou emocionais. A partir destes rótulos, ou o aluno (geralmente de classe economicamente baixa) é promovido para a série seguinte por compaixão, ou é reprovado por castigo, ou ainda pode ser encaminhado para 'turmas especiais'.

É a uma outra concepção de aprendizagem e de linguagem que Deleuze (1987, p.22) se refere quando afirma:

Nunca se sabe como uma pessoa aprende: mas de qualquer forma que aprenda, é sempre por intermédio de signos, perdendo tempo, e não pela assimilação de conteúdos objetivos. Quem sabe como um estudante pode tornar-se repentinamente 'bom em latim', que signos (amorosos ou até inconfessáveis) lhe serviram de aprendizado? Nunca aprendemos alguma coisa nos dicionários que nossos pro- fessores e nossos pais nos emprestam. O signo implica em si a heterogeneidade como relação.

Aqui o aprender é tomado como movimento, como construção/desconstrução, como exercício de invenção que não é linearmente conduzido por um conteúdo específico mas por signos sensíveis que vão além de uma concepção de linguagem em suas funções de informação e comunicação.

Já em sua obra Proust e os signos, Deleuze problematiza a complexidade das relações implicadas na linguagem. Posteriormente, em Lógica do Sentido, amplia essas discussões, afirmando que muitos autores concordam em reconhecer três dimensões clássicas da proposição: a designação, a manifestação e a significação. No entanto, a consideração dessas dimensões entre si, segundo o autor (DELEUZE, 2000), formaria um círculo fechado que daria conta de explicar as relações lógicas da linguagem, mas não diria respeito ao seu princípio de organização que conviria para explicar os efeitos incorporais de superfície (os acontecimentos). Desse modo, para além das palavras, das coisas, das imagens e das idéias há uma outra dimensão que, insiste e subsiste na proposição, ainda que não possa ser inferida a não ser indiretamente. Esta dimensão é o sentido.

É um pouco acerca das relações entre as dimensões clássicas da proposição e suas implicações no campo pedagógico que se trata agora de problematizar. Antes, porém, parece importante considerar que a tentativa de separação da proposição em diferentes dimensões é meramente didática. Em seu funcionamento, não há primado de uma sobre a outra: "Da designação à manifestação, depois à significação, mas também da significação à manifestação e à designação, somos conduzidos em um círculo que é o círculo da proposição" (DELEUZE, 2000, p.15).

\section{APRENDIZAGEM E DESIGNAÇÃO}

A dimensão da designação, indicação ou ainda denominação é quem estabelece relações entre as proposições e o estado de coisas que lhes são exteriores. Assim, a designação diz respeito ao preenchimento das palavras, à associação da palavra a imagens particulares selecionadas por corresponderem a cada estado de coisas em particular (não se tratando de conceitos gerais ou universais). Ela opera "pela associação das próprias palavras com imagens particulares que devem representar o estado de coisas" (op.cit., p.13). Desse modo, entre todas as coisas possíveis de serem 
representadas por uma palavra, torna-se necessário selecionar aquela que melhor se adapta, que corresponde à proposição manifesta.

A designação relaciona-se com o verdadeiro e o falso: são verdadeiras as proposições preenchidas por um estado de coisas, as imagens que correspondem às coisas e, por oposição, são falsos os designantes que não efetuarem tal correspondência, seja por defeito ou por impossibilidade de seleção da imagem (op.cit., p.13).

Ela diz respeito àquilo de que se fala, ao objeto, remetendo, assim, ao extralingüístico. Segundo Blikstein (1999, p.23), a questão do referente $^{2}$, das relações com o extralingüístico, vem sendo discutida não somente pelas variadas correntes lingüísticas e semiológicas, mas também pela antropologia, pelas teorias do conhecimento e outras áreas do conhecimento interessadas nas relações entre linguagem, pensamento, conhecimento e realidade. Já nos estóicos era possível encontrar a relação triádica envolvendo o signo, o significado e o referente (a coisa). No entanto, à medida que o significado já era concebido como produto de um contrato ou código social, durante muito tempo as relações entre significado e significante foram eleitas como as mais importantes, em detrimento das relações entre coisa extralingüística e significado, tomadas como mais ou menos diretas. As dimensões social e cultural estariam, desse modo, sendo contempladas. No entanto, para Blikstein (1999, p.24)

em que pese a longa tradição de uma teoria ternária do signo, a situação da coisa ou objeto extralingüístico tem sido uma questão nebulosa: na verdade, a inclusão do referente não implicou a captura da realidade extralingüística. Pelo contrário, paradoxalmente, foi até um modo de descartála da lingüística e da semiologia, afrouxando ou rompendo eventuais e promissores laços entre estas e a psicologia, a antropologia e a teoria do conhecimento.

Assim, o referente, o extralingüístico (objeto mental ou unidade cultural) continuou, por longo tempo, à margem dos estudos lingüísticos na explicação dos mecanismos de produção do significado, ainda que sempre mostrando sua presença. Para Blikstein (op.cit.), a exclusão deve-se, principalmente, à consideração dos mecanismos perceptivos-cognitivos como inatos ao funcionamento humano o que, por sua vez, levou a uma negligência dos estudos em relação à função e ao papel destes na configuração do real e da arquitetura conceitual de nosso pensamento. Tomadas como categorias inatas, a cognição e a percepção definiriam, a priori, estruturações objetivas e universais da realidade e que, por esse motivo, não precisariam ser questionadas.

Ainda segundo o mesmo autor, é somente por um caminho tortuoso, a partir de Greimas e Coseriu, que o referente começa a ser tomado como construção perceptivo-cognitiva o que, por sua vez, cria a necessidade de incluí-lo nos estudos da significação não mais como estruturas objetivas da realidade mas como estruturações impostas à realidade pela interpretação humana. Assim, a afirmação: "a língua recorta a realidade" é substituída por uma outra que diz "ela não recorta a realidade propriamente, mas o referente ou a realidade 'fabricada"' (BLIKSTEIN, 1999, p. 47).

$\mathrm{Na}$ esteira dessa ruptura com a neutralidade do ver, sentir, olhar, ouvir, pensar, encontramse, entre outros, autores como Deleuze e Guattari (1987, p.27)

Ser sensível aos signos, considerar o mundo como coisa a ser decifrada é, sem dúvida, um dom. Mas esse dom correria o risco de permanecer oculto em nós mesmos se não tivéssemos os encontros necessários; e esses encontros ficariam sem efeito se não conseguíssemos vencer certas crenças.

Assim, para que possamos entender a linguagem como produtora do mundo, a primeira crença que deve ser destruída, para Deleuze, é o objetivismo, ou seja, atribuir ao objeto os signos de que é portador. "Pensamos que o próprio objeto traz o segredo do signo que emite e sobre ele nos fixamos, dele nos ocupamos para decifrar o signo" (DELEUZE, 1987, p.27). Não queria com isso, o autor, reivindicar a supressão da dimensão designadora da linguagem. Mas participar de uma crítica à sua compreensão como operação naturalizada, que leva à crença de que a realidade é algo dado a ser descoberto, desvelado - o que impediria de pensar o mundo como invenção maquínica social.

Blikstein (1999) denominou "óculos sociais" ao que faltava a Kaspar Hauser para conseguir enxergar o mundo civilizado. Apesar da aquisição da linguagem, Kaspar Hauser continuava descodificando de modo aberrante a significação do mundo, vendo-o como um amálgama de manchas. Em Deleuze e Guattari (1992), esses "óculos sociais" podem ser entendidos como imagem de pensamento. A imagem que se dá do pensar, do fazer uso do pensamento, ou seja, os pressupostos implícitos, subjetivos, pré-conceituais 
Elias, C.R.; Axt, M "Quando aprender é perder tempo... compondo relações entre linguagem, aprendizagem e sentido"

que formam uma imagem do pensamento, que traçam o plano de consistência (ou de imanência) no movimento de fabricação do mundo.

Assim, colar a palavra à coisa constitui uma crença de um tipo de imagem de pensamento que se expressa por uma visão do mundo como representação. Ao contrário, para Deleuze e Guattari, o mundo é produção maquínica. Sob esse ponto de vista, a linguagem não representa as coisas, mas as produz ao mesmo tempo que é por elas produzida.

No campo escolar, tal crença se atualiza como concepção de aprendizagem pela recognição, pelo reconhecimento. Fala-se, oficialmente, do mundo (designado) a partir de um discurso científico que tem o poder, e só ele o tem, de desvendálo.

A linguagem, nesse contexto de designação, concebida a partir de uma natureza transparente, de um código neutro e explícito, funciona como instrumento de descrição de uma realidade que é por ela representada. Fazendo crer que a palavra relaciona-se diretamente às coisas, desde o século XIX, o discurso pedagógico, legitimado pelo discurso científico, como manifestante, assume um tom de veracidade inquestionável. Latour (2000, p.33-34), referindo-se à constituição do mundo moderno e a seus vínculos com a representação, diz:

cabe à ciência a representação dos não humanos, mas lhe é proibida qualquer possibilidade de apelo à política; cabe à política a representação dos cidadãos, mas lhe é proibida qualquer relação com os não-humanos produzidos e mobilizados pela ciência e pela tecnologia.

Essa relação também é produzida pela divisão em disciplinas das áreas humanas e das áreas exatas nos currículos escolares. Divisão entre ciências falsas e ciências verdadeiras. As primeiras, proscritas, ligadas ao contexto social. "Quanto às ciências sancionadas, apenas se tornam científicas porque se separam de qualquer contexto, qualquer traço de contaminação, qualquer evidência primeira, chegando mesmo a escapar de seu próprio passado" (LATOUR, 2000, p.92).

Desse modo, a representação científica, em última instância, marcaria a própria fala do designado, à medida que seus procedimentos funcionam por um processo objetivo de desvelamento do mundo, de busca e de descoberta da verdade do objeto.

Reconhecemos as coisas sem jamais as conhecermos. Confundimos o significado do signo com o ser ou o obje- to que ele designa. Passamos ao largo dos mais belos encontros, nos esquivando dos imperativos que eles emanam: ao aprofundamento dos encontros, preferimos a facilidade das recognições (...) (DELEUZE, 1987, p.27)

A dimensão da designação tomada como operação de representação do real pode ser ampliada para a busca da objetividade científica no campo escolar. Segundo Latour, o trabalho da modernidade envolve uma relação complexa entre dois conjuntos de práticas separadas: um que cria, por purificação, a divisão entre humanos e nãohumanos - é o trabalho da crítica de separação e classificação do mundo; e o segundo que "cria, por tradução, misturas entre gêneros de seres completamente novos, híbridos de natureza e cultura" (LATOUR, 2000, p.16). As duas práticas são complementares. Sem o trabalho de purificação, de separação, não haveria cada vez mais híbridos a serem enfrentados e, sem o trabalho de representação, a classificação seria inútil, "as práticas de tradução seriam vazias e supérfluas" (op.cit., p.16).

\section{APRENDIZAGEM E MANIFESTAÇÃO}

Diferente da designação, a manifestação é a dimensão da proposição que se reporta ao sujeito que fala ou que se exprime. É ela que marca a existência de manifestantes na proposição, como partículas especiais: eu, tu; amanhã, sempre, alhures, em toda parte, etc. Constitui, assim, o domínio do pessoal e serve de princípio a toda designação possível. "Eu é o manifestante de base" (DELEUZE, 2000, p.14).

Ao se referir às dimensões da proposição, Deleuze faz menção a uma possível articulação entre a dimensão da manifestação e o advento da subjetividade moderna cartesiana do ponto de vista do deslocamento que propicia o surgimento do sujeito consciente. O "eu penso", como manifestante, funda a concordância de todas as faculdades (interiores ao sujeito) e seu acordo na forma de um mesmo suposto objeto considerado o mesmo. Daí seus critérios de julgamento serem a veracidade e o engano, em relação a uma consciência.

Por outro lado, também faz referência a uma suposta articulação entre a dimensão da designação e a filosofia grega que, ao contrário da moderna, buscava desvelar um mundo exterior já dado, que se manifestava por sua própria força interna e possuía em si mesmo a inteligibilidade. Daí os critérios da designação serem o verdadeiro ou o falso, em relação ao mundo/objeto externos. "Enfim, da designação à manifestação se produz um 
deslocamento de valores lógicos representado pelo Cogito: não mais o verdadeiro e o falso, mas a veracidade e o engano" (DELEUZE, 2000, p.14).

Desse modo, na proposição, "do lado do estado de coisas, tem-se a crença de que os objetos estão à espera de articulações que lhes confiram existência; do lado dos sujeitos, tem-se o desejo de produção de um signo que corresponda a um determinado estado de coisas" (SILVA, 2003, p.75).

A manifestação, portanto, diz respeito a quem diz. No campo escolar, a fala oficial é a do professor. Segundo Orlandi, uma das características do discurso pedagógico é que ele se pretende científico e o estabelecimento dessa cientificidade pode ser observado especialmente em dois pontos, na metalinguagem e na apropriação do cientista feita pelo professor (tanto em nome de quem ele fala quanto nos livros didáticos que utiliza).

O professor apropria-se do cientista e se confunde com ele sem que se explicite sua voz de mediador. Há aí um apagamento, isto é, apaga-se o modo pelo qual o professor apropriase do conhecimento do cientista, tornando-se ele próprio possuidor daquele conhecimento. (ORLANDI, 1996, p.21)

Conforme a autora, o processo de apropriação da voz do cientista pelo professor é feito através de um apagamento da mediação. Latour (2000), no entanto, vai além, ao propor que a própria voz do cientista é apagada em favor da voz do objeto (que é desvelado e, portanto, se revela). É possível encontrar aqui, novamente, as mesmas operações das práticas de tradução, mediação, referidas anteriormente. Em última instância, é o objeto que fala pela voz do cientista e, portanto, por extensão, pela voz do professor.

Os cientistas são representantes escrupulosos dos fatos. Quem fala quando eles falam? Os próprios fatos, sem dúvida nenhuma, mas também seus porta-vozes autorizados. Quem fala, então: a natureza ou os homens? (...) Os cientistas, porém, afirmam não falar nada: os fatos falam por si mesmos. (LATOUR, op.cit., p.34)

Ao professor cabe falar e, na sua fala, repetir um discurso científico. É sob este ponto de vista que ele cala, porque representa. É a voz do saber que fala no professor e, ao mesmo tempo, o legitima em seu lugar de suposto saber - ele já passou pelo (re)conhecimento.

Como manifestante de segunda ordem, o aluno aprende que deve reconhecer e repetir o que é dito por um discurso científico que se expressa através da voz do professor. Seu lugar na relação com o saber é o do não-saber. O caminho a ser trilhado é o do (re)conhecimento dos saberes que lhe são transmitidos como verdadeiros. Compõese, assim, a cadeia de um modo de conceber o aprender pelo (re)conhecimento, na articulação entre as três dimensões da proposição: o aluno (re)conhece o saber do professor que fala pela voz do cientista (manifestantes) que, por sua vez, (re)conhece o saber de uma ciência (significação) que, por sua vez, também (re)conhece o saber de uma natureza que deve ser decifrada (designação). A indissociabilidade das três dimensões da proposição confere, então, um status de verdade inquestionável ao modo de aprender como (re)conhecimento do saber, do lugar do manifestante, da voz do objeto.

Em relação à dimensão da manifestação, a problematização passa pelos deslocamentos que a concepção de sujeito vem sofrendo desde o fim do século XIX, na esteira de Friedrich Nietzsche que anuncia a morte de Deus e a passagem à formahomem como uma forma a ser ultrapassada. Desde então, a noção de sujeito veio sendo desestabilizada através de rupturas provocadas na cultura ocidental.

Com Copérnico, o homem deixou de estar no centro do universo. Com Darwin, o homem deixou de ser o centro do reino animal. Com Marx, o homem deixou de ser o centro da história (que aliás não possui centro). Com Freud, o homem deixou de ser o centro de si mesmo (que também não existe, é apenas um lugar vazio, uma brecha, uma voragem). (Coelho, s/d, p. XXXVIII)

Também Deleuze alia-se a essa imagem de pensamento que apresenta um homem descentrado, dominado por forças que desconhece e que o constituem como forma (SILVA, 1997). Nessa perspectiva, tanto a dimensão da designação como da manifestação marcam o atravessamento de concepções filosóficas na linguagem. Assim como a crítica à designação não se fazia em uma perspectiva de aniquilamento, mas se dirigia a uma certa crença cega na sua capacidade de referência, ou seja, no objetivismo, também a crítica à manifestação não se constrói em si mesma. O que Deleuze nega é a relação entre o "eu" manifestante e um sujeito consciente que seria a origem do seu dizer. O "eu" marca, antes, uma enunciação individuada, prisioneira de significações 
Elias, C.R.; Axt, M "Quando aprender é perder tempo... compondo relações entre linguagem, aprendizagem e sentido"

dominantes, porque colada a fluxos/cortes dos funcionamentos maquínicos coletivos de enunciação. Com Guattari (1995b, p.13), escrevem: "Existem muitas paixões em uma paixão, e todos os tipos de voz em uma voz, todo um rumor, glossolalia: isso porque todo o discurso é indireto, e a translação própria à linguagem é o discurso indireto".

\section{APRENDIZAGEM E SIGNIFICAÇÃO}

A terceira relação da proposição é a significação ou demonstração. A significação é responsável pela articulação entre o plano da expressão e o plano do conteúdo, os quais, como signos, podem remeter sempre a outras proposições, capazes de servir de premissas à primeira. "Tal cadeia não estabelece, como a designação, uma relação direta entre a proposição e o estado de coisas, mas age por procedimentos indiretos, referindo-se, sempre, a outras proposições das quais ela é concluída ou, inversamente, cuja conclusão ela torna possível" (SILVA, 2003, 77).

De tal mecanismo não se podem inferir verdades ou falsidades. É possível somente estabelecer as condições de produção dos discursos verdadeiros. Condições essas que não têm como oposição a falsidade, mas o absurdo, ou seja, o que não pode ser nem verdadeiro nem falso.

Do ponto de vista da linguagem, o plano de conteúdo se configura na crítica à autonomia dos objetos (referente), opondo-se a uma tradição segundo a qual o signo é, antes de mais nada, signo de alguma coisa. É contra essa crença no objetivismo, na representação, que Deleuze e Guattari (1995b) se voltam, propondo o conceito de agenciamento maquínico do desejo (ampliação do plano do conteúdo hjelmsleviano) que remete à construção cultural/social do significado. Ou seja, a linguagem não representa um objeto natural. Ela se refere a um estado de coisas, a corpos que são, desde sempre, culturalmente produzidos.

Paralelamente, o plano de expressão surge da crítica do sujeito consciente que cognitivamente produz o mundo a partir de uma identidade, de uma interioridade que se exterioriza. Contra este subjetivismo, Deleuze e Guattari (1995b) propõem o conceito de agenciamento coletivo de enunciação (ampliação do plano de expressão hjlelmsleviano). É desse modo que o "eu" da enunciação não diz respeito a um sujeito que se manifesta, mas a uma forma individuada, prisioneira das significações dominantes.

As crenças no objetivismo e no subjetivismo fornecem os princípios de um modo de pensar que Deleuze denomina de senso comum, cujas opera- ções são a identificação e o reconhecimento. Subjetivamente, é operação do senso comum organizar o "eu" em uma identidade, em uma unidade: "é um só e mesmo eu que percebe, imagina, lembra-se, sabe, etc.; e que respira, que dorme, que anda, que come..." (DELEUZE, 2000, p.80) e, objetivamente, é ele que "subsume a diversidade dada e a refere à unidade de uma forma particular de objeto ou de uma forma individualizada de mundo: é o mesmo objeto que eu vejo, cheiro, saboreio, toco, o mesmo que percebo, imagino e do qual me lembro (...)" (op.cit., p.80). Dito de outro modo, a uma ordem das idéias corresponde uma ordem das coisas.

Nessa perspectiva, poderíamos dizer que a escola, ancorada por esse modo de pensar, contribui para 'ensinar' o aluno a mergulhar neste mundo de reconhecimento do que é dito pelo outro (professor/ciência). Ensinar é transmitir/inculcar, aprender é (re)conhecer. No entanto, diz Deleuze (1988, p.223): "A forma da recognição nunca santificou outra coisa que não o reconhecível e o reconhecido, a forma nunca inspirou outra coisa que não fossem conformidades".

Este modelo de aprendizagem como recognição, segundo o autor, está compreendido na imagem que temos do pensamento. É ele que tem orientado o nosso modo de pensar o que é o pensar, a partir de uma "faculdade de identificação, que relaciona uma diversidade qualquer à forma do Mesmo" (DELEUZE, 2000, p.80).

À operação do senso comum, das identidades fixas, articula-se a do bom senso como sentido único a ser seguido. "O senso comum identifica, reconhece não menos que o bom senso prevê" (op.cit. p.80). Contribui, assim, para organizar a diversidade em um grande todo coerente, previsível e para fazer crer em uma única direção a ser seguida.

A dimensão da significação poderia, nessa perspectiva e de certa forma, como resultado da articulação entre plano de conteúdo e plano de expressão, contribuir para a crítica da representação. No entanto, segundo Deleuze e Guattari, ela mesma tem seus limites. Ou seja, ela torna-se autoreferencial. Se uma significação sempre se baseia em outra já constituída, então acaba ela mesma sendo responsável pela produção das condições de verdade. $\mathrm{E}$, desse modo, acaba fazendo a proposição dobrar-se sobre si mesma, enclausurando-a novamente nas significações dominantes.

Segundo os autores, essa seria a face estratificada, o aspecto de território dos agenciamentos maquínicos. "Enquanto os agenciamentos permanecem submetidos à distinção do 
conteúdo e da expressão, continuam pertencendo aos estratos, e pode-se considerar que os regimes de signos, os sistemas pragmáticos constituem, por sua vez, estratos (...)" (DELEUZE; GUATTARI, 1995c, p.219), linhas de integração que se colam às significações dominantes na tendência de repetílas.

A articulação entre as significações dominantes e a lógica da proposição através dos significantes lingüísticos logo e implica produzem um efeito de demonstração. Recupera-se a certe$\mathrm{za} /$ verdade através do procedimento indireto validado pelas condições de verdade, ou seja, pelo conjunto das condições sob as quais uma proposição seria verdadeira (na seqüência lógica na qual uma remete à outra como premissa ou conclusão). É o argumento lógico que fornece aqui o testemunho da verdade ou falsidade, em contraposição ao absurdo, que é o que não pode ser nem verdadeiro nem falso.

Do ponto de vista da aprendizagem, a significação forja a certeza como modo de funcionamento comprovado (pela demonstração). A processualidade como constitutiva da aprendizagem não pode ser mantida, já que o objetivo é chegar a um ponto. Descarta-se a categoria do problemático, a possibilidade de experimentação, a dúvida, os conflitos como elementos do próprio processo. A aprendizagem vai de um ponto a outro, transmitida por uma linguagem/mensagem. O ponto a se chegar são os conceitos científicos fechados, universalizantes, comprovados pelos sistemas de significação, contrapondo-se a uma aprendizagem que, concebida como construção/ desconstrução conceitual, implica a compreensão do conceito como campo híbrido, como todo fragmentário e aberto.

Nessa perspectiva, Demo (1999), chega a opor práticas pedagógicas centradas no ensino, que se esforçam por passar certezas que devem ser reconfirmadas nas provas, a práticas que tendem a valorizar a aprendizagem buscando "a necessária flexibilidade diante de uma realidade apenas relativamente formalizável, valorizando o contexto do erro e da dúvida. Pois, quem não erra e nem duvida, não pode aprender".

Assim, ainda no ambiente escolar, a dimensão da significação poderia ser tomada como as regras que regem a prática pedagógica, direcionadas a ensinar aos sujeitos, professores e alunos, como ensinar e aprender. Comportamentos, atos corretos, metodologias, currículos pré-determinados, conhecimentos sistematizados e transmitidos numa ordem crescente e verticalizada. Regras que incluem também a premissa do dever evitar o conflito, seja nas relações interpessoais, seja no processo de apreensão dos conteúdos, das normas. Uma aprendizagem lógica das significações dominantes: repetir o que foi descoberto, reproduzir experiências já feitas, estudar regras e postulados, evidenciar certezas.

A dimensão da significação fecharia, desse modo, o círculo da proposição a partir de uma articulação entre mundo (objeto), sujeito que se manifesta e regras que lhe conferem organização e coerência. Tal circunscrição se liga ao modelo comunicacional emissor-mensagem-receptor que compõe, articulado à concepção de aprendizagem como transmissão de informação/conhecimento, a hipótese de um modo de aprender homogêneo, linear, previsível.

No entanto, segundo Deleuze e Guattari (1995c, p.219), os agenciamentos maquínicos não se compõem somente de uma face estratificada, ou seja, um território é sempre inseparável dos movimentos de desterritorialização. Segundo essas linhas de desterritorialização, "o agenciamento já não apresenta expressão nem conteúdos distintos, porém, apenas matérias não formadas, forças e funções desestratificadas". Portanto, para os autores, também nas significações dominantes algo vaza, desloca-se permanentemente.

\section{PROBLEMATIZANDO A}

\section{APRENDIZAGEM E O SENTIDO}

Por quais mundos andariam nossos alunos enquanto falamos (excessivamente)? Quais deles escutam e em quais momentos se dispersam? O que entendem? No que pensam? Quando são afetados e instigados a pensar? Quais relações estabelecem? Quando estariam reproduzindo modelos através de memorização? Quando estariam aprendendo? De quais modos? Quais suas questões?

Não se pretende aqui que essas perguntas sejam respondidas. Formuladas nesses termos, nem parece possível. Apenas busca-se compor uma cena escolar cotidiana para trazer a idéia da aprendizagem como multiplicidade, movimento permanente, e assim, construir um caminho para tratar do sentido, na direção de uma perspectiva de Deleuze, como criação/invenção no processo do aprender.

Ao analisar a obra de Proust, o autor assim se refere ao aprendizado:

Nada aprendemos com aquele que nos diz: faça como eu. Nossos únicos mestres são aqueles que nos dizem 'faça comigo' e que, em vez de nos proporem gestos a serem reproduzidos, sabem emitir signos a serem desenvolvi- 
Elias, C.R.; Axt, M "Quando aprender é perder tempo... compondo relações entre linguagem, aprendizagem e sentido"

dos no heterogêneo. (DELEUZE, 1988, p.54)

Para Deleuze (2000), as relações entre as três dimensões da proposição, designação, manifestação e significação, produzem um efeito de linguagem organizada. No entanto, não podem explicar os seus movimentos: seu princípio de organização, segundo o qual ela própria seria linguagem e sua (da linguagem) alta potência de falar sobre as palavras.

Para isso seria preciso ir além das dimensões clássicas da proposição e considerar uma quarta dimensão: o sentido. Diz Deleuze: "É difícil responder àqueles que julgam suficiente haver palavras, coisas, imagens e idéias" (op.cit., p.21), porque o sentido não é algo que existe mas que subsiste e insiste. Não estando nem nas coisas, nem nas proposições, no entanto

é o exprimível ou o expresso da proposição e o atributo do estado de coisas. Ele volta uma face para as coisas, uma face para as proposições. (...) É neste sentido que é um "acontecimento" (...) O acontecimento pertence essencialmente à linguagem, ele mantém uma relação essencial com a linguagem: mas a linguagem é o que se diz das coisas. (DELEUZE, 2000, p.23)

O sentido/acontecimento diria, assim, da trama constituída pelo deslizamento permanente, produzido pelos efeitos das proposições e pelos efeitos da mistura de corpos. "Tudo se passa na fronteira entre as coisas e as proposições", diz Deleuze (op.cit., p.9), tudo se produz na superfície a partir de alguma coisa que não tem existência, mas que, ainda assim, insiste e subsiste.

O sentido/acontecimento é uma descoberta dos estóicos para quem na natureza só existiam $\operatorname{corpos}^{3}$. Natureza e linguagem são corpos. O exprimível, segundo Nef (1995, p.31):

Ontologicamente é um incorporal, epistemicamente é o conteúdo de um pensamento, lingüisticamente é a significação de uma frase acabada (...) Os exprimíveis incompletos - os verbos - são atributos incorporais dos corpos. (...) O exprimível, a rigor, não é, ou não existe: subsiste. (...) é, portanto, um quase-ente, uma quase-coisa. Dizer que ele subsiste é dizer que ele supera a oposição entre existir e não existir.

O sentido/acontecimento é um duplo incorporal. Enquanto o primeiro (sentido), diz respeito ao expresso da proposição, o segundo remete ao efeito da mistura de corpos. "Mas, na medida em que os acontecimentos-efeitos não existem fora das proposições que os exprimem, esta dualidade se prolonga na das coisas e das proposições, dos corpos e da linguagem" (DELEUZE, 2000, p.26). Desse modo e conforme o autor, como expresso da proposição, o sentido é atributo da mistura de corpos, ou seja, as proposições falam dos efeitos dessas misturas de corpos (acontecimento) e, como efeito destas misturas, o acontecimento tende a ser exprimível pelo sentido. "O sentido é a mesma coisa que o acontecimento, mas desta vez relacionado às proposições. E ele se relaciona às proposições como seu exprimível ou seu expresso, completamente distinto do que elas significam, do que elas manifestam e do que elas designam (...)" (op.cit.,p.172).

Como incorporal, o sentido constitui-se por paradoxos, por devires, por singularidades. Segundo Deleuze (2000, p.31), nos instalamos sempre no sentido "para operar as designações possíveis e mesmo para pensar suas condições". No entanto e, paradoxalmente, nunca dizemos o sentido do que expressamos. Como expresso da proposição, mas não se confundindo com ela, o sentido tem o poder de proliferação, de falar sobre as próprias palavras. Ou seja, sempre que se tenta explicar o sentido de alguma proposição, ele foge, é sempre movimento de passagem, jogo de forças, potência. Mas se não dizemos aquilo que pensamos podemos sempre tomar o sentido do que dizemos como objeto de uma outra proposição, da qual, por sua vez, não dizemos o sentido. A esse paradoxo do sentido Deleuze chama de paradoxo da regressão ou da proliferação indefinida (2000, p31-32).

Poder-se-ia infinitamente tentar capturar o sentido de uma primeira enunciação em uma regressão infinita; no entanto, o que se conseguiria seria fazê-lo proliferar cada vez mais, ou seja, quanto mais se tenta explicar, mais os sentidos proliferam, vazam por diferentes direções. Esse paradoxo da regressão/proliferação, para Deleuze, "dá testemunho, ao mesmo tempo, da maior impotência daquele que fala e da mais alta potência da linguagem: minha impotência em dizer o sentido do que digo, em dizer, ao mesmo tempo, alguma coisa e seu sentido, mas também o poder infinito da linguagem de falar sobre as coisas" (op.cit., p.31).

Segundo o mesmo autor, sempre que se começa a falar já estamos instalados no sentido. Portanto, ainda que não se confunda com as proposições, é ele quem as gera. Essa outra face do sentido marca, além da sua característica de proliferação, também o seu poder genético. A partir da articulação de forças virtuais, singularidades, é o 
sentido que organiza as dimensões clássicas da proposição através de formalização.

Não há mais por que voltar a insistir sobre o caráter essencialmente produzido do sentido: jamais originário, mas sempre causado, derivado. (...) E este poder genético, nestas condições, devemos sem dúvida compreendê-lo com relação à própria proposição, na medida em que o sentido expresso deve engendrar as outras dimensões da proposição. (op.cit., p.98)

Mas, novamente, ao mesmo tempo em que se formaliza nas proposições, a produtividade do sentido é estéril, ou seja, esgota-se no exprimir. Este é o paradoxo ao qual Deleuze denomina de paradoxo do desdobramento estéril ou da reiteração seca. É ele que faz "conjugar a esterilidade do sentido com relação à proposição de onde o extraímos, com sua potência de gênese quanto às dimensões da proposição" (DELEUZE, 2000, p.35).

É este o poder genético do sentido: puro movimento de intensidades num jogo de forças que atualiza algumas formas não determinadas previamente, e não outras. Não é explicável, nem por um inconsciente individual, nem coletivo, porque é pré-pessoal, pré-individual. Se fossemos seguir seus fluxos, toda uma sociedade reapareceria, todo um universo estaria presente e, ainda assim, não diríamos o seu sentido, porque ele próprio "cria os caminhos que traça e faz bifurcar" (op.cit., p. 98).

Sequer seria possível imobilizar o sentido já que, a cada vez que se expressa, ele morre ao se exprimir. Ele é, ao mesmo tempo, estéril com relação à proposição de onde o extraímos, e potente em relação à gênese da proposição.

No limite, em relação à linguagem, poderíamos dizer que só existe um outro signo, porque o primeiro era incompleto em função do sentido que sempre vaza e que faz a linguagem se modificar permanentemente. Nessa perspectiva, a linguagem não é somente algo que conhecemos, mas é algo vivo, sempre em processo que não se define somente pelas regras lógicas, por uma lógica do discurso, mas também pelos paradoxos, pelo que foge, em suma, pelo sentido.

\section{CONSIDERAÇÕES FINAIS}

Dois modos de aprender foram propostos. Um primeiro que supõe a aprendizagem como transmissão direta de informações/conhecimentos e, portanto, como movimento homogêneo para todos os alunos. Processo que vai de um ponto a outro, percorrendo um trajeto cuja importância seria menor em relação aos resultados a serem alcança- dos no final.

A concepção do aprender como transmissão se articula a uma concepção de linguagem transparente, que iria idealmente de um emissor/ professor a um receptor/aluno. Compõem-se, assim, a cadeia de um modo de conceber o aprender pela operação de (re)conhecimento, na articulação entre as três dimensões clássicas da proposição que, circunscritas em um círculo fechado sobre si mesmo, aliam-se às teorias representacionais: o aluno (re)conhece o saber do professor que, por sua vez, (re)conhece e fala pela voz do cientista (manifestantes), que (re)conhece o saber de uma ciência (significação), que, por sua vez, também (re)conhece o saber de uma natureza/cultura que deve ser decifrada (designação). Nessa perspectiva, para os alunos adaptados ao modo escolar, a aprendizagem se dá por operações de reconhecimento a partir de caminhos pré-determinados que devem ser seguidos. O que foge a essas orientações, considera-se dispersão. Nos casos de persistência na dispersão, encontram-se classificados os alunos com 'problemas de aprendizagem'.

Poder-se-ia dizer que uma imagem de pensamento arborescente, segundo Deleuze e Guattari (1995a), dá forma a este modo de pensar o aprender pelo reconhecimento. Se a árvore pode ser pensada como a imagem do mundo, no caso do aprender escolar, é a informação, mediada pela linguagem, que representa este mundo.

Um outro modo de aprender se atualiza, quando se concebe a aprendizagem como construção/desconstrução de conceitos/conhecimentos. Nessa perspectiva, o aprender supõe a processualidade e, desse modo, não pode ser concebido como movimento que percorre uma linha estratificada, indo de um ponto a outro, mas sim por movimentos rizomáticos de um pensamento que é afetado por modos e intensidades diferentes, produzindo caminhos diferenciados, linhas que se articulam a outras se produzindo incessantemente.

É o incorporal que se impõe aqui como puro movimento de forças virtuais que, sendo impessoal e pré-individual, se formaliza na proposição e já não é mais ele próprio a forma que criou. Mas o que insiste e subsiste. Se o poder genético do sentido organiza a linguagem em proposições, é ele também que fala sobre as palavras, arrastando a proposição ao movimento paradoxal da proliferação indefinida.

Desse modo, conceber a aprendizagem como processualidade implicaria considerar, também, a dimensão do sentido/acontecimento como o incorporal que, violentando o pensamento, forja caminhos inesperados e diferenciados no apren- 
Elias, C.R.; Axt, M "Quando aprender é perder tempo... compondo relações entre linguagem, aprendizagem e sentido"

der. É o movimento que produz questionamentos a partir de arranjos muitas vezes inusitados. As questões são fabricadas como qualquer outra coisa, diz Deleuze (1998, p.9): "Se não deixam que você fabrique suas questões, com elementos vindos de toda parte, de qualquer lugar, se as colocam a você, não tem muito o que dizer".

Não há uma linguagem transparente que coordene e dirija estes caminhos, indo do emissor/professor ao receptor/aluno. O processo do aprender é atravessado pelo movimento violento do sentido que irrompe, foge, vaza. Daí a necessidade de considerá-lo em sua imprevisibilidade. Se, por um lado, os conceitos/conhecimentos tendem a um fechamento, como territórios formando um todo, todo território é inseparável dos movimentos de desterritorialização, assim como o conceito é inseparável do devir à medida que constitui sempre um todo fragmentário (DELEUZE, 1992).

É nessa perspectiva que se entende que uma concepção de aprendizagem como processualidade exige partida, abandono do território, encontro com os híbridos, com as misturas, com a desorganização. É a aprendizagem como desafio. Marcada, muitas vezes, pela dor, pelo sofrimento, por dúvidas e incertezas. São as linhas de fuga que vão se produzindo, sem eira nem beira, como rizomas. Buscando aqui e ali um território (teórico) em meio a desterritorializações. Qualquer ponto pode se conectar a outro, qualquer linha pode ser rompida, quebrada em algum lugar e também retomada segundo uma ou outra de suas linhas e mesmo segundo outras linhas (DELEUZE; GUATTARI, 1995a, p.18). Qualquer linha pode também se transformar em arborescência, ser estratificada.

A aprendizagem, nessa perspectiva, pode ser pensada como um pensar que não se movimenta espontaneamente e nem sequer é dirigido pelo que deve ser dito a partir do reconhecimento. Não há boa vontade em pensar, diz Deleuze. O pensamento é violentado por encontros imprevisíveis, por intensidades diferenciadas. "(...) o que nos violenta é mais rico do que todos os frutos de nossa boa vontade ou de nosso trabalho aplicado; e mais importante do que o pensamento é 'aquilo que faz pensar"' (DELEUZE, 1987, p.30).

Mas o autor também salienta a decepção como elemento do aprender. A decepção pode ser tomada por uma espécie de preguiça, que acionaria a resistência e impediria, assim, a atualização de outra dimensão do aprender que é a do enfrentamento do medo do caos, da desorganização. É da relação entre essas duas faces que se constitui o movimento do aprender. Por sua vez, o enfrentamento do caos exige uma certa organiza- ção do pensamento que não é homogênea, mas se constitui através da produção de caminhos diferenciados para cada aprendiz (ainda que tomados por imagens de pensamento de determinadas épocas). É este movimento de organização sempre provisória e instável, atual/virtual que se constitui em criação. Nessa perspectiva se poderia pensar um movimento da arte no aprender como processo, que se contrapõe ao aprender como reconhecimento. Preferir o aprofundamento dos encontros à facilidade das recognições, diz Deleuze

De fato, uma revelação parcial aparece em determinado campo de signos, mas é acompanhada às vezes de regressões em outros campos, mergulha numa decepção mais geral, pronta para reaparecer em outros campos, sempre frágil enquanto a revelação da arte ainda não sistematizou o conjunto. E, a cada instante, também pode acontecer que uma decepção particular faça surgir a preguiça e comprometa o todo. (DELEUZE, 1987, p. 27)

Quais implicações teriam estas considerações nas práticas pedagógicas? Por um lado, uma concepção de aprendizagem como transmissão de informações implicaria práticas pedagógicas formalistas, que desconsideram a criação como constitutiva do processo de aprendizagem.

Mas, por outro lado, práticas que levassem somente em conta a criação, o trabalho do sentido, poderiam cair em um relativismo absoluto: todas as formalizações são válidas, todos os pontos de vista são possíveis. Se a homogeneidade tende a criar espaços estriados, que tentam enclausurar os movimentos de criação, também as práticas de respeito a toda e qualquer possibilidade de interpretação, no caso da aprendizagem escolar, tendem a criar espaços lisos que correm o risco de perderem-se em si mesmos, tornando-se improdutivos porque "(...) quanto menos as pessoas levarem a sério o pensamento, tanto mais pensarão conforme o quer um Estado" (DELEUZE; GUATTARI, 1995c, p.46).

Desse modo, o que constituiriam práticas pedagógicas que procurassem "cuidar do sentido" e suas relações com a ética, conforme expressão utilizada por Deleuze em Lógica do Sentido?

Fazer do sentido o objeto de uma nova proposição, é isto 'cuidar bem do sentido', em condições tais que as proposições proliferam, 'os sons tomam conta de si mesmos'. Confirma-se a possibilidade de um laço profundo entre a lógica do sentido e a ética (...). 
(2000, p.34)

A resposta mais próxima, neste momento, parece ir em direção à consideração da dimensão política do aprender: cuidar bem do sentido e suas relações com a ética passa pela invenção de práticas criativas de aprendizagem; em oposição a práticas autoritárias, de subordinação que, segundo Deleuze, constituiriam o pensar como quer um Estado.

\section{NOTAS}

${ }^{1}$ Tema desenvolvido na Tese de Doutorado de ELIAS, Carime R., orientada pela Profa. Dra. Margarete Axt.

${ }^{2}$ Segundo o autor, Ogdens e Richards lançaram a figura do referente como a coisa extralingüística diferenci-ando-o de referência, ou significado lingüístico.

${ }^{3}$ Segundo Deleuze (2000), o sentido/acontecimento foi descoberto duas outras vezes: nos séculos XVI e XIX.

\section{REFERÊNCIAS}

BLIKSTEIN, I. Kaspar Hauser ou a fabricação da realidade. São Paulo: Cultrix, 1999.

COELHO, E. P. Estruturalismo - antologia de textos teóricos. Rio de Janeiro: Martins Fontes, s/d.

DELEUZE, G. Proust e os signos. Rio de Janeiro: Forense Universitária, 1987.

DELEUZE, G. Diferença e Repetição. Rio de Janeiro: Graal, 1988.

DELEUZE, G. Lógica do Sentido. $4^{\mathrm{a} e d, ~ S a ̃ o ~ P a u l o: ~}$ Perspectiva, 2000.

DELEUZE, G. Foucault. $4^{\mathrm{a}}$ ed. São Paulo: Brasiliense, 1998.

DELEUZE, G. Conversações. Rio de Janeiro: Editora $34,2000$.

DELEUZE, G.; GUATTARI, F. Mil Platôs - Capitalismo e Esquizofrenia. V.1, Rio de Janeiro: Editora 34, 1995a.

DELEUZE, G. Mil Platôs - Capitalismo e Esquizofrenia. V.2, Rio de Janeiro: Editora 34, 1995b.

DELEUZE, G. Mil Platôs - Capitalismo e Esquizofrenia. V.5, Rio de janeiro: Editora 34, 1995c.
DELEUZE, G. O que é a Filosofia? Rio de Janeiro: Editora 34, 1992.

DELEUZE, G.; PARNET, C. Diálogos. São Paulo: Escuta, 1998.

DEMO, P. Educação e Desenvolvimento - análise crítica de uma relação quase sempre fantasiosa. In: Rastros (Revista do Núcleo de Estudos em Comunicação), IELUSC, Joinvile/SC, Ano 1, N. 1, dez. 1999, p. 69 - 113.

ELIAS, C. R. (Des)Caminhos do aprender: uma perspectiva teórico-metodológica que aproxima aprendizagem e sentido/acontecimento. Porto Alegre: UFGRS, 2003. Tese (Doutorado em Educação).

LATOUR, B. Jamais fomos modernos. 2. ed. São Paulo: Editora. 34, 2000.

NEF, F.. A linguagem - uma abordagem filosófica. Rio de Janeiro: Jorge Zahar, 1995.

ORLANDI, E. P. A Linguagem e seu Funcionamento - as formas do discurso. Campinas, São Paulo: Pontes, 1996.

SILVA, A. R. A Morte do Homem e o Império da Intertextualidade - uma experiência tropicalista. In: Semiótica e Pragmática da Comunicação (org. Elizabeth Bastos Duarte). Cadernos de Comunicação. São Leopoldo: Editora da Universidade do Vale do Rio dos Sinos, n. 3, 1997.

SILVA, A. R. Elementos para uma Comunicação Pós-Midiática. São Leopoldo: UNISINOS/RS, 2003. Tese (Doutorado em Comunicação). 
Carime Rossi Elias é Doutora em Educação pela Faculdade de Educação da Universidade Federal do Rio Grande do Sul. Atualmente docente da

FACED/UFRGS.

$O$ endereço eletrônico da autora é: carime@terra.com.br

Margarete Axt é Professora titular da Faculdade de Educação da Universidade Federal do Rio

Grande do Sul (FACED/UFRGS). Docente no

Programa de Pós-Graduação em Educação (PPGEDU) e no Programa de Pós-Graduação em Informática na Educação (PPGIE). Coordenadora do LELIC/UFRGS (Laboratório de Estudos em Linguagem, Interação e Cognição) da FACED/UFRGS.

O endereço eletrônico da autora é: maaxt2002@yahoo.com.br

Quando aprender é perder tempo.... compondo relações entre linguagem, aprendizagem e sentido

Carime Rossi Elias

Margarete Axt

Recebido: 16/03/2004

Aceito: 01/06/2004 